Рад примљен: 19. 1. 2016.

Рад прихваћен: 6. 4. 2016.

Josip A. Sliško'

Facultad de Ciencias Físico Matemáticas, Benemérita Universidad Autónoma de Puebla, Puebla, México

Прегледни рад

doi: $10.5937 /$ inovacije1602001S

\title{
Improving teaching design of active physics learning by using potentially helpful knowledge from other science fields
}

\begin{abstract}
Although today's economy depends a lot on knowledge and learning skills of workers, lecture-based physics teaching, whose essence is "active teacher delivers content to passive students", often does not provide to the students needed knowledge and learning-skills. According to educational research, active physics learning is better than passive learning. Nevertheless, there are two problems in the implementation of active physics learning: many students know little or nothing about labormarket importance of learning skills and about complexity of learning process. Being so, they are not sufficiently motivated to change their routine approach to learning (formed in lecture-based teaching) and, even when they try to be more active, they face various difficulties due to the complexity of human learning. Informing students extensively about these important issues and giving them multiple opportunities for practicing and improving self-regulated learning might have positive effects in their academic results. An original sequence model for fostering explicitly self-regulated learning, online and in classroom, is briefly presented, too.
\end{abstract}

Key words: Self-regulated learning, knowledge-based economy, knowledge workers, active physics learning.

\section{Introduction}

"Economy in knowledge societies" (Cook, 2001) and "companies and organizations that learn " (Nonaka i Takeuchi, 1995) cannot exist without people who are prepared and able to apply creatively old and efficiently learn or produce new knowledge. These are the basic characteristics of a grow-

1 josipslisko47@gmail.com ing category of employees that are called "knowledge workers".

Ability of better and faster learning is the only comparative advantage, both of companies and individuals at the global market of labour and capital, which is exposed to continuous changes, always faster and less predictable. Traditional fields of management, related to material resources, production processes and selling strategies, today became, more 
and more, "knowledge management" and "learning management" (Harvard Business Review, 1998).

Higher-education institutions have a very important social responsibility in education of "knowledge workers", who should be prepared to face, not only today's known problems, but more future unknown problems which will appear in next decades. (Jarvis, 2001; Graham, 2002).

Nevertheless, the university teaching, even in the most industrialized countries like the USA, is slow and unprepared to react adequately to these urgent economic needs. In their thought-provoking book "We're Losing Our Minds Minds. Rethinking American Higher Education", Keeling and Hersh say:

"The truth is painful but must be heard: we're not developing the full human and intellectual capacity of today's college students because they're not learning enough and because the learning that does occur is haphazard and of poor quality. Too many of our college graduates are not prepared to think critically and creatively, speak and write cogently and clearly, solve problems, comprehend complex issues, accept responsibility and accountability, take the perspective of others, or meet the expectations of employers. Metaphorically speaking, we are losing our minds." (Keeling \& Hersh, 2012, p. 1).

According to Keeling and Hersch, one of the main causes of this situation is teaching-centered culture of colleges and universities:

"Since teaching is what matters and what is measured, instruction is mostly lecture-driven and learning, to the extent that it occurs, is mostly passive, receptive enterprise. In other words, students should come to class, listen carefully, take good notes, and be grateful.“ (Keeling \& Hersh, 2012, p. 20)

To make things worst, standards-based measuring of conceptual learning and knowledge appli- cability in solving real-world problem is rarely carried out or it is completely absent.

Keeling and Hersh consider that learning, needed by actual knowledge-based economy,

“...requires that students be fully engaged participants in a powerful intellectual, social, and developmental process. That process requires rigorous self-discipline, effort, and commitment; demanding well-trained teachers; an inspiring, motivating, and diverse curriculum; and an intentionally designed, challenging, formative, and supportive learning environment." (Keeling \& Hersch, 2012, p. 20).

Amazing analysis of Keeling and Hersh related to American higher education has been carried out from a general point of view, without entering into details of any specific field of knowledge. So, it is interesting to explore how much it fits the situation in physics education.

\section{Teaching and learning in traditional physics education}

The bad news is that lecture-based teaching and passive and receptive students' learning still dominate actual physics education.

The good news is that there are people, forming a growing community of Physics Education Research (PER), who are interested in

(a) measuring real learning outcomes of physics teaching, and

(b) designing better learning sequences and environments.

Their works produced an impressive research literature, which goes from students conceptual difficulties in physics learning to experimentally proven teaching strategies which help students advance in physics understanding (McDermott \& Redish, 1999; Tacker, 2003). For many physics topics there are standard tests for measuring levels of concep- 
tual understanding, like »Force Concept Inventory« (Hestenes, Wells \& Swackhamer, 1992) for mechanics and »Conceptual Survey for Electricity and Magnetism« (Maloney et al., 2001) for electromagnetism.

The results of lecture-based physics teaching are not satisfactory (McDermott, 1991; McDermott, 1993):

Conceptual learning is poor or absent.

Functional knowledge is not present.

Students are not able to apply high-order thinking procedures (like going from one to another representation or from abstract definitions and formulas to real word and back).

Problem-solving skills are confused with formula-based algorithmic games.

Why traditional lecture-based physics teaching does not work?

The basic cause of failure is that this approach to teaching has behind it an erroneous theory of learning, which considers that the essence of learning is reception and memorizing of a clear instructional message. In other words, that approach does not take into account how humans learn (Bransford, Brown \& Cocking, 2001). It is almost a trivial fact that humans learn best by doing things, by making and correcting errors.

In order to do things perfectly, humans need to constantly improve their performances. Beside a lot of step-after-step practice, they also must think critically and creatively on what they do. It is well understood in sports and music. Nobody will learn to swim listening someone talking about swimming (and about Stokes' force) nor will someone learn to play violin listening someone talking about violin playing (and about Fourier transformations).

\section{A new paradigm in physics education: Active physics learning}

Active physics learning or activity-based physics learning is gaining popularity in physics education (Meltzer \& Thornton, 2012). It is becoming a promising new paradigm which will, sooner or later, replace old paradigm codified in lecture-based teaching and passive learning. It is important to stress that active physics learning paradigm in physics teaching was not inspired and forced by general active learning movement in education (Bonwell \& Eison, 1991; Harmin, 1994). Physics education researchers empirically discovered some elements of active physics learning paradigm to solve annoying problem of unsatisfactory conceptual students' learning that was the result of lecture-based teaching.

There are now enough experimental evidences that physics researchers were successful in solving that problem. Namely, active learning approach is obviously better regarding conceptual learning than lecture-based teaching (Hake, 1998; Deslauriers, Schelew \& Wieman, 2011)

Nevertheless, above-mentioned disconnection from other educational and other scientific fields is not good for the future of physics education. Namely, as it will be shown later, some problems in active physics learning might call for an interdisciplinary approach.

What is an instruction that promotes active learning? There are some general answers to this question, like:

"...Instruction involving students in their own learning more deeply and more intensely than does traditional instruction, particularly during class time" (Meltzer \& Thornton, 2012),

“...Instructional method that engages students to shift from a passive to an active role in the learning environment" (Prince, 2004) 
More informative and practical instructional approach has, as its starting point, the following pedagogical belief:

In order to learn physics, students should do physics: observe, describe, explain and predict physical phenomena.

In all these thinking processes, students make use of their previous ideas and experiences. When previous ideas do not work, students try new ones, proposed by them or by teacher.

New knowledge is the result of sense making of new experiences. In order that this sense-making process comes out as a successful one, students should experience, and be conscious of, a "conceptual change" (Dykstra, Boyle \& Monarch, 1992; Galili, 1996).

There are many physics-course designs that, in general terms, promote active learning, but differ in details.

Priscilla Laws (Dickinson College) designed the first lecture-free physics course, called "Workshop physics", in which students learn physics by doing physics (Laws, 1996; Laws, 1997). Students in the classroom, with the help of computers, take data about phenomena and make sense of them. Halliday \& Resnick textbook is used as a resource material to find out needed information. Its content is not lecture-based delivered to the students in the classroom.

Eric Mazur (Harvard University) designed a method of active learning in which "students teach students" (Mazur, 1997). This is done through peer discussions of subtle points they did not understand by reading assignments (which replace delivery of content). Mazur only "teaches" those parts of the content which students did not comprehend by themselve.

Examples of some other courses, based on the paradigm of active physics learning, are:
Student-Centered Active Learning Environment for University Physics or SCALE-UP, authored by Robert Beichner at the North Caroline State University (Beichner, 2008);

Technology-Enhanced Active Lerning or TEAL, designed by John Belcher at the MIT (Dori \& Belcher, 2005), and

Investigative Science Learning Environment or ISLE, developed by Eugenia Etkina and Alan van Huevelen at the Rutgers (Etkina \& van Heuvelen, 2001).

The most popular sequence of active learning is Predict - Observe - Explain. Although this sequence was has been used long time ago by Piaget in his research of children's thinking, carried out with the use of clinical interviews, it was introduced in science teaching, without mentioning Piaget, by White and Gunstone under acronyme POE (Predict - Observe - Explain) (White \& Gunstone, 1992).

In order that this sequence works, it is necessary that students first have (according to their criterions) a sense situation about which they can answer questions. In answering such questions, students activate their intuitive ideas about how material world works or should work.

As can be concluded from its name, the Predict-Observe-Explain sequence consists of three steps.

In the first step, through prediction task about how a physical phenomenon or its simple modification will work, student personally activates and formulates his or her alternative ideas about considered physical phenomenon: What do I expect that will happen? Why do I expect that this must or might happen?

In this way, any student has an opportunity to predict personally an outcome of a simple experiment and to conceptually justifies his or her prediction. In this step, especially during elaboration of prediction justification, alternative ideas about 
functioning of particular segments of physical world are activated and explicitly formulated.

When personal predictions and justifications are formulated, then group discussion of those predictions and justifications comes, with the aim to reach consensus, meaning a group prediction and justification. It is important to tell students that everyone can keep personal prediction and justification, if not completely satisfied with different prediction and justification (Sliško \& Medina Hernandez, 2005).

The second step is observation and comparison between personal and group prediction and observation. In the case of well thought learning situation, the prediction and observation do not coincide. By this difference an „epistemological disequilibrium" has been produced and the students by themselves conclude that their thinking about the studied phenomenon (or some of its modifications) is not adequate.

In the third step, students have a challenging task to explain the noted difference and to propose a change in the suppositions and reasoning their prediction was based on. The objective of the change is that the new prediction fits the observation.

An illustration of Predict-Observe-Explain sequence implementation is students' consideration of the behavior of a jet that flows out of a plastic bottle through a hole made in its wall (Corona, Sliško i Planinšič, 2006). Even after the students saw that the jet stopped flowing out when the bottle was in free-fall, they do not expect that the jet will stop flow when the bottle is launched up. Their prediction, for the situation when the bottle is moving freely up, is that the jet will not stop flowing out and that the flow will be faster. After seeing that their prediction does not fit the observation (the jet stops flow out also when the bottle is moving freely up), the students are ready to reconsider critically their situation model and to change it.

\section{Some problems with classroom implementations of active physics learning}

As it was said before, active physics learning approach was invented to improve physics conceptual learning. Students are exposed to new learning demands, without being informed that such change will improve not only their physics learning but also their learning skills in general. In addition, students are not given information about the importance of good learning skills in knowledge-based economy.

Active learning is a drastic rupture with students' old learning routine (memorization, repetition, imitation), which seemed before to work quite well. Being so, many students are reluctant to make the change (Sliško \& Medina Hernandez, 2005). To motivate them, it is important to talk about potential labor-market benefits of skills that can be achieved in active learning. In fact, long time ago it was suggested that "conceptual change" is not only driven by "cold" cognitive factors but that it depends a lot on motivational and contextual variables (Pintrich, Marx \& Boyle, 1993).

Of course, the information should be taken from recent economic literature and should be well stated to be convincing for and able to increase motivation of students.

The other problem is that students know very little or nothing about the complexity of learning process. It is not a wonder because their conceptualization of learning is based on the worst possible learning experience, provided by lecture-based teaching. In this type of teaching, students frequently construct a belief that their thinking and doubts are unnecessary because they only spoil "learning" which is basically being able to memorize and repeat what was said by teacher or was written in the textbook. They also believe that they can only learn something if it is explained by the teacher.

Such a belief leads to the situation that some students, frequently low-achievers, do not want to formulate and discuss their ideas. 
To make a change in their learning behavior, students should be

(1) explicitly and broadly informed about complexity of learning process and crucial importance of personal thinking and ideas in that process, and

(2) given multiple experiences with learning sequences which will help them recognize that complexity and the importance of full personal engagement.

One additional problem is that some good students do not want to participate in group learning. They feel it as an unnecessary waste of time in which they teach others, less able students, doing the job the teacher is paid for.

In what follows, I will firstly present information from economic literature about the importance of learning skills. This information should be shared and discussed with students in order to increase their motivation for learning behavior change, so much needed to make possible active physics learning and corresponding conceptual and methodological changes in students thinking and doing.

Then, I will briefly introduce the paradigm of self-regulated learning that is a broader framework than usually practiced "active physics learning".

Finally, I will present a possible teaching design that might promote self-regulated learning.

\section{Learning skills are a top economic need}

It is good to start with a ground-breaking diagnosis of Chris Argyris in the article with provoking title "Teaching smart people how to learn":

"Any company that aspires to succeed in the tougher business environment of the 1990s must first resolve a basic dilemma: Success in the marketplace increasingly depends on learning, yet most people don't know how to learn.
What's more, those members of the organization that many assume to be the best at learning are, in fact, not very good at it." (Argyris, 1991)

As Argyris was working as a consultant with many chief executive officers of important transnational companies, his diagnosis about absence of learning skills, even at the highest organizational levels, can hardly be an eccentric exaggeration and extravaganza. So, the message is important:

Organizational and personal future depends on learning, so everybody has to learn how to learn.

Peter Drucker has stressed another crucial aspect of learning, especially for those who are or will be knowledge workers. Learning is a never-ending, life-long process:

"The most valuable asset of a 21 st-century institution (whether business or non-business) will be its knowledge workers and their productivity. Knowledge work requires continuous learning on the part of the knowledge worker, but equally continuous teaching on the part of the knowledge worker." (Drucker, 1999)

The idea of learning-teaching role exchange speaks about collective nature of knowledge work. In active physics learning, during group phase, students can get first experiences on how „teaching others" can improve one's own learning and thinking.

Another important characteristic of a productive knowledge-worker is that she or he must be self-managed and self-regulated. For achieving that state, one has to know how to learn and how to work with others:

"Knowledge workers must, effectively, be their own chief executive officers. It's up to you to carve out your place, to know when to change course, and to keep yourself engaged 
and productive during a work life that may span some 50 years. To do those things well, you'll need to cultivate a deep understanding of yourself - not only what your strengths and weaknesses are but also how you learn, how you work with others, what your values are, and where you can make the greatest contribution." (Drucker, 2005)

Both ideas (learning-teaching connection and working with others) are very important arguments to share and discuss with good students who are reluctant to take part in the group learning.

Other authors stress the same ideas, using other wording. Peter Senge speaks about "working together":

"Delivery of content is less and less what schools are going to be about; educators are going to have to give that up. The opportunity in this is that schools can be more focused on the social aspects of learning - the soul of real education, which is kids learning together, learning how to work out their differences, learning how to work together." (Senge, 2012)

Tim Wagner (2008) has included „collaboration" among five surviving skills for the XXI century:

\section{Critical thinking and problem solving; Collaboration and leadership;}

Effective oral and written communication;

Finding and analyzing information;

Curiosity and imagination.

It is important to note that many labor skills needed and appreciated in knowledge-based economy are (or might be) practiced and improved in active physics learning. Sharing and discussing this connection adequately with students might motivate many of them to participate better in physics learning activities.
An important element in good functioning of active physics learning is the assumption that every student will sincerely participate both in personal and collective phase of learning. Speaking about the importance of "working with others" and "collaboration skills" may convince high-achievers to participate more in the group work.

As it was said above, it often happens that low-achievers among students try to avoid written formulation of their personal ideas and arguments, waiting to see or hear what will "more able" students write or say. Doing so, the precious classroom time reserved for personal thinking is lost.

There are, at least, two basic ways out of this unproductive situation.

One possibility is that every student delivers her or his personal answer or thinking, using intelligent mobile phone before attending the group discussion. Students' answers could be collected and stored, for example, by the cost-free software Socrative (Mendez Coca \& Slisko, 2013a; Mendez Coca \& Slisko, 2013b).

Along the same line, Prof. Mazur and his group have developed a sophisticated platform, called Learning Catalytics, which makes possible automatic collection and analysis of students' verbal, graphic and symbolic answers, promoting maximal students' engagement in active physics learning (Schell, Lukoffi Mazur, 2013).

The other possibility is that the personal phase is given as an obligatory homework whose results have to be delivered to the teacher via e-mail, before classroom group session. If some course administration platform (for example, Moodle) is used for giving the homework and receiving the results, it would be possible to have time control for doing homework and delivering students' answers. In this way, it would be possible to reduce or eliminate copying. To reduce copying, the teacher might, additionally, design an adequate assessment policy in which autonomous personal work (even with conceptual or 
procedural errors) would be awarded while „cloned answers" would be drasticly punished.

\section{The essence of active learning: self-regulated learning how to learn}

Active physics learning, as actually designed and practiced in physics education, is only a part of a more complex and much elaborated conception, called "self-regulated learning" (Pintrich, 1995; Low \& Jin, 2012; Zimmerman \& Schunk, 2013).

So, a very challenging and far-reaching approach to design of active physics learning would be to inform students about the complexity of the learning process and to give them opportunities to practice learning within the self-regulation paradigm.

Regarding metacognitive aspects of learning, self-regulated learners plan, set goals, organize, self-monitor, and self-evaluate gained results at various points during the learning process. They are also very motivated, showing high self-efficacy, selfattribution and intrinsic task interest. In addition, self-regulated learners know and accept that learning results are better with more efforts and persistence and within an adequate learning environment (Zimmerman, 1990). The success of self-regulated learning depends of students' abilities to activate and use in the best way metacognitive, motivational and behavioral resources and strategies.

Generally speaking, self-regulated learning process consists of three different phases:

Forethought or planning phase;

Performance phase; and

Self-reflection phase (Zimmerman, 2002)

In the Planning phase, students activate all necessary knowledge and skills to understand the given problem and make a plan how to solve it.

In the Performance phase, they monitor how they perform, whether some unexpected or unclear details appear, and verify validity of partial and final solution.

Self-reflection phase is the most important part of self-regulated learning. In it, students are supposed to look back and evaluate critically their performance and what was learned and what was not. In the last case, they try to determine what possible causes might be of their unsuccessful learning. In order to assist students in their self-reflective performance, students should be provided with an adequate and timely feedback at every stage of implemented learning sequence.

A possible sequence of combined classroom and online physics learning, which would likely induce in many students self-regulated approach to learning, might be:

1. Homework (delivered online): personal approach to the learning task with explicit formulation of doubts and difficulties.

2. Classroom: group approach to learning task in classroom, solving personal doubts and difficulties and defining eventual group doubts and difficulties (group report delivered online).

3. Online reading: expert approach to learning task with comments on group doubts and difficulties, prepared by the teacher.

4. Homework (delivered online): final selfreflection on learning experience (what I did right and wrong?).

In addition, formative and summative assessment should award personal ideas and arguments not only for correctness but also for clearness or originality. Students appreciate when we are interested in what and how they think and when their initial thinking is not punished or subject of laugh.

Learning from self-recognized and self-corrected personal and group errors seems to be a better way to construct knowledge and skills than di- 
rect instruction (Kapur, 2012; Siler, Klahr \& Price, 2013).

Initial implementations of the above teaching design, inspired by the paradigm of self-regulated learning, were carried out with students taking a course of optics, with the collaboration of Dr Zalkida Hadzibegovic (University of Sarajevo, Boasnia and Herzegovina) and students taking a course of higher mathematics, with the collaboration of Prof. Maria Araceli Juárez Ramírez (Autonomous University of Puebla, Mexico). In both cases, students were very satisfied with the experiences got and results they achieved. More details about both implementations will be given in some future publications.

\section{Conclusions}

There is a general agreement among economic writers that learning skills are crucially important in knowledge-based global economy. Some authors even name this economy „learning economy“ (Hyysalo, 2009; Johnson, 2011). Surprisingly, students at many schools and universities are rarely or never taught explicitly how to learn. Instead, they are given a dangerous illusion that careful listening to the lecture-based delivery of course content leads necessarily to good learning results.

In physics education, through implementations of instructional designs that promote active physics learning, there are experimental evidences that a progress in conceptual learning is possible. This fact is, even, recognized in the literature on economics teaching and learning and is taken as an example to follow (Maier \& Simkins, 2012).

Nevertheless, the progress is not gained in all students. So, there is a need to look for improved teaching designs that might make that more students learn how to learn, especially among those students who are low achievers.

In my view, knowledge and writings from actually economic literature might be useful to motivate students. Informing students about self-regulated learning paradigm and providing systematically learning tasks that foster such a behavior could give them useful perspective on the complexity of human learning.

This proposal, which advocates more usage of theoretical and experimental knowledge from selfregulated learning paradigm, goes well with a programatic idea, stated by Heron and Meltzer in their guest editorial "The future of physics education research: intellectual challenges and practical concens":

„Collaboration between between members oft he PER and cognitive science communities in designing and conducing experiments relevant to physics education could be useful and productive." (Heron y Meltzer, 2005).

\section{Acknowledgement}

- The main part of this article was prepared and written during author's sabbatical research project "Active physics learning online" supported by CONACyT Mexico for the period August 2012 - July 2013.

\section{References}

- Argyris, C. (1991), Teaching smart people how to learn, Harvard Business Review, 4(2), 99 - 109.

- Beichner, R. (2008). The SCALE-UP Project: A student-centered, active learning environment for undergraduate programs. An invited white paper for the National Academy of Sciences. 
- Bransford, J. D., Brown, A. L. \& Cocking, R.R. (editors) (2001). How People Learn. Brain, Mind, Experience, and School. Expanded Edition. Washington, D.C.: National Academy Press.

- Bonwell, C. C. \& Eison, J. A. (1991). Active Learning. Creating Excitement in the Classroom. Washington: The George Washington University

- Cooke, P. (2001). Knowledge Economies: Clusters, Learning and Co-Operative Advantage. London: Routledge.

- Corona, A, Sliško, J. \& Planinsic, G. (2006). Rising freely bottle also demonstrates weightlessness. Physics Education, 41(3), 8 - 9 .

- Deslauriers, L., Schelew, E. \& Wieman, C. (2011). Improved Learning in a Large-Enrollment Physics Class, Science, 332(6031), 862 - 864.

- Dori, Y. J., \& Belcher, J. (2005). How does technology-enabled active learning affect undergraduate students' understanding of electromagnetism concepts?. The Journal of the Learning Sciences, 14(2), 243-279.

- Drucker, P. F. (1999), Knowledge-worker productivity: The biggest challenge, California Management Review, 41(2), 79-94.

- Drucker, P. F. (2005). Managing Oneself. Harvard Business Review, 83(1) 100- 109.

- Dykstra, D. I., Boyle, C. F., \& Monarch, I. A. (1992). Studying conceptual change in learning physics. Science Education, 76(6), 615-652.

- Etkina, E., \& Van Heuvelen, A. (2001). Investigative science learning environment. In APS Forum on Education Newsletter (pp. 12-14).

- Galili, I. (1996). Students' conceptual change in geometrical optics. International Journal of Science Education, 18(7), 847-868.

- Graham, P. A. (editor). (2002). Knowledge Economy and Postsecondary Education: Report of a Workshop. Washington, DC: National Academic Press.

- Hake, R. R. (1998). Interactive-engagement versus traditional methods: A six-thousand-student survey of mechanics test data for introductory physics courses, American Journal of Physics, 66(1), 64-74.

- Harmin, M. (1994). Inspiring Active Learning. A Handbook for Teachers. Alexandria: Association for Supervion and Curriculum Development.

- Harvard Business Review (1998). Harvard Business Review on Knowledge Management. Harvard: Havard Business School Press.

- Heron, P. R. L. \& Meltzer, D. E. (2005). The future of physics education research: Intellectual challenges and practical concerns, American Journal of Physics, 73(5), 390-394.

- Hestenes, D., Wells, M., \& Swackhamer, G. (1992). Force concept inventory. The physics teacher, 30(3), 141158.

- Hyysalo, S. (2009). Learning for learning economy and social learning. Research Policy, 38(5), 726-735.

- Jarvis, P. (editor) (2001). The Age of Learning: Education and the Knowledge Society. London: Taylor and Francis Group.

- Johnson, B. (2011). From user-producer relations to the learning economy. Science and Public Policy, 38(9), 703-711.

- Kapur, M. (2012). Productive failure in learning the concept of variance. Instructional Science, 40(4), 651672. 
- Keeling, R. P. \& Hersh, R. H. (2012). We're Losing Our Minds. Rethinking American Higher Education. New York: Palgrave Macmillan.

- Laws, P. W. (1996). Workshop Physics Activity Guide Modules 1-4, New York, NY: John Wiley and Sons.

- Laws, P.W. (1997). Millikan Lecture 1996: Promoting active learning based on physics education research in introductorz physics courses. American Journal of Physics, 65(1), 14-21.

- Low, R., \& Jin, P. (2012), Self-Regulated Learning In Encyclopedia of the Sciences of Learning (pp. 3015-3018), New York: Springer.

- Maier, M., \& Simkins, S. (2012). Learning from physics education research: lessons for economics education, in Hoyt, G.M. \& McGoldrick, K.M. (editors) (2012). International Handbook on Teaching and Learning Economics. Cheltenham, UK: Edward Edgar Publishing (pp. 384 - 392).

- Maloney, D. P., O’Kuma, T. L., Hieggelke, C. J., \& Van Heuvelen, A. (2001). Surveying students' conceptual knowledge of electricity and magnetism. American Journal of Physics, 69(S1), S12-S23.

- Mazur, E. (1997). Peer Instruction: A User's Manual. Upper Saddle River, NJ: Prentice Hall.

- McDermott, L. C. (1991). Millikan Lecture 1990: What we teach and what is learned - Closing the gap. American Journal of Physics, 59(4), 301-315.

- McDermott, L. C. (1993). Guest Comment: How we teach and how students learn-A mismatch? American Journal of Physics, 61(4), 295-298.

- McDermott, L. C. \& Edward F. Redish, E. F. (1999). Resource Letter: PER-1: Physics Education Research, American Journal of Physics, 67(9), 755-767.

- Meltzer, D. E. \& Thornton, R. K. (2012). Resource Letter ALIP-1: Active-Learning Instruction in Physics. American Journal of Physics, 80(6), 478-496.

- Méndez Coca, D. \& Slisko, J. (2013a). Software Socrative and smartphones as tools for implementation of basic processes of active physics learning in classroom: An initial feasibility study with prospective teachers, European Journal of Physics Education, 4(2), 17-24.

- Méndez Coca, D. \& Slisko, J. (2013b). The influence of active physics learning on reasoning skills of prospective elementary teachers: A short initial study with ISLE methodology, Latin American Journal of Physics Education, 7(1), 3-9.

- Nonaka, I. \& Takeuchi, H. (1995). The Knowledge-Creating Company. New York: Oxford University Press.

- Pintrich, P. R., Marx, R. W., \& Boyle, R. A. (1993). Beyond cold conceptual change: The role of motivational beliefs and classroom contextual factors in the process of conceptual change. Review of Educational research, 63(2), 167-199.

- Pintrich, P. R. (1995). Understanding self-regulated learning. New directions for teaching and learning, 1995(63), 3-12.

- Prince, M. (2004). Does active learning work? A review of the research. Journal of Engineering Education, 93(3), 223-231.

- Schell, J., Lukoff, B. \& Mazur, E. (2013). Catalyzing Learner Engagement using Cutting-Edge Classroom Response Systems in Higher Education, u C. Wankel i P. Blessinger (editors) (2013). Increasing Student Engagement and Retention Using Classroom Technologies: Classroom Response Systems and Mediated Discourse 
Technologies (Cutting-edge Technologies in Higher Education, Volume 6). Bingley, UK: Emerald Group Publishing Limited, pp. 233-261.

- Senge, P. (2012) A Systems Approach to Tranformation in Education. Conference at the Master Class and Forum - Denver Metro Chamber Leadership Foundation, November 14, 2012. Siler, S. A., Klahr, D. \& Price, N. (2013). Investigating the mechanisms of learning from a constrained preparation for future learning activity. Instructional Science, 41(4), 191-216.

- Sliško, J. \& Medina Hernandez, R. (2005). Uspjesi i teškoće jedne implementacije paradigme "aktivnog učenja” u sveučilišnoj fizici. Metodicki ogledi (Zagreb, Croatia), 12(2), 79-94.

- Thacker, B. A. (2003). Recent advances in classroom physics. Reports on Progress in Physics, 66(10), 18331864.

- Wagner, T. (2008). Rigor redefined. Educational Leadership, 66(2), 20-25.

- White, R. \& Gunstone, R. (1992). Probing Understanding. London and New York: The Falmer Press.

- Zimmerman, B. J. (1990), Self-regulated learning and academic achievement: An overview, Educational psychologist, 25(1), 3-17.

- Zimmerman, B. J. (2002), Becoming a self-regulated learner: An overview, Theory into practice, 41(2), 64-67.

- Zimmerman, B. J., \& Schunk, D. H. (Editors), (2013), Self-regulated learning and academic achievement: Theoretical perspectives, New York: Routledge. 


\section{Јосип А. Слишко}

Физичко математички факултет,

Самостални Универзитет Пуебла, Пуебла, Мексико

\section{Унапређивање наставе за активно учење физике коришћењем потенцијално корисног знања из других научних области}

Резиме: Савремена ілобална економија из дана у дан све више зависи оу иррименливоі знана и одређених вешитина учена зайолсних. Поучаване физике иреgаванима, у чијој

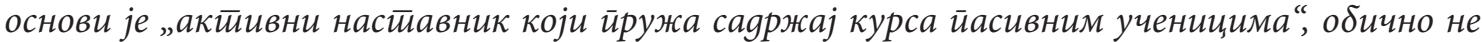

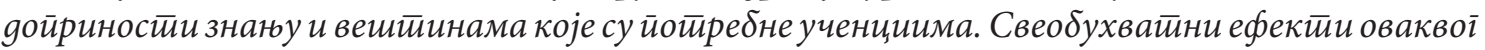
начина учена и йоучавана се оілеgају у слеgећем: йојмовно знане је лоше, нема вишеі нивоа

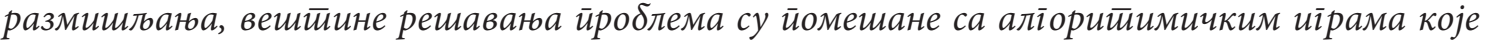
су засноване на формулама. Према истраживанима у образовану, акииивно учене физике

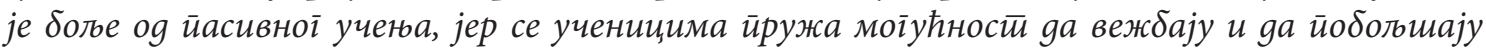
иоменуйо знане и вешитине. Најбољи начин gа се учи физика је на начин сличан научној иракси и сииварној йракси. Друі им речима, йо значи gа акииивно учене физике йоgразумева

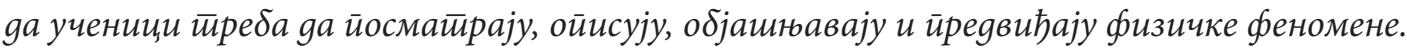

Актиивно учеюе физике, којесе оянеgавно ирримеюује, йостиаје свейойуларниеуучиониии, захвалујући йримерима који се заснивају на истиражианима и који су ирреgстиавльени $у$

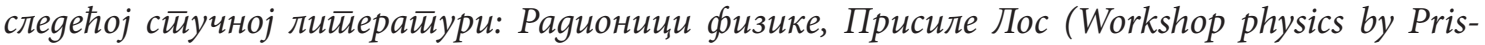
cilla Laws), Врињачко йоучаване Ерика Мазура (Peer Instruction by Eric Mazur), Окружење

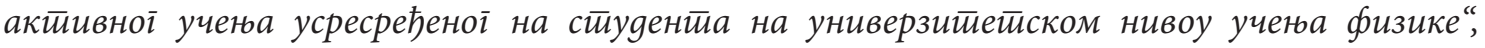
Pоберйа Бајхнера (Student-Centered Active Learning Environment for University Physics by Robert Beichner) Технолошки обухваћено акииивно учење Џона Бечлера (Technology-Enhanced Active Learning by John Belcher) и Истираживачко окружене за учене йриродних наука Јущиније Ейикне и Алена Ван Хуавелена (Investigative Science Learning Environment by Eugenia Etkina and Alan van Huevelen).

Ийак, йостиоје gва неgовољно ирроучена ироолема у вези са осмишљьвағем и

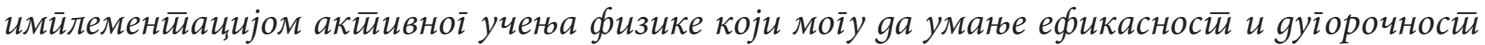

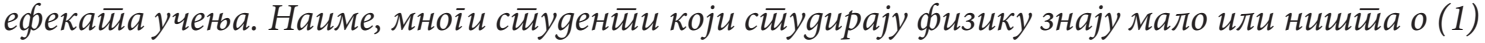

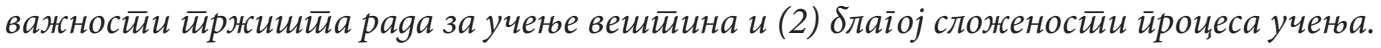

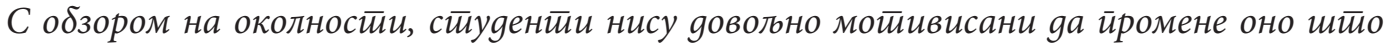

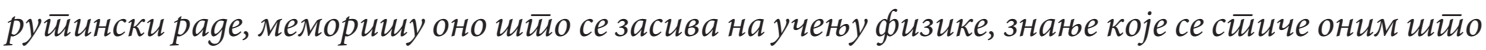

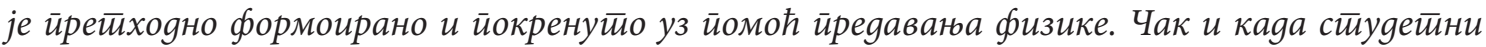
йокушају gа буgу акйивнији и gа се уgубе у учене физике, они наилазе на мноіе йойешкоће

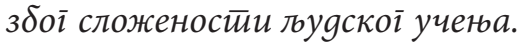

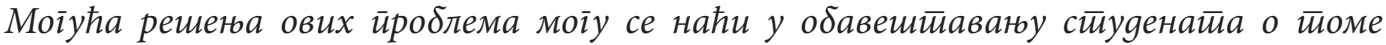
колико су важне вешитине учена у економији која се заснива на знану и у йоме gа им се

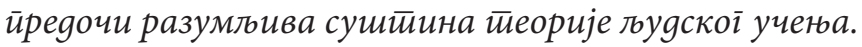




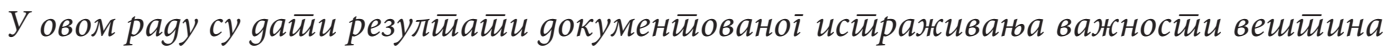
учею а у економској и литиерайури која има везе са економијом, gајући оgі̄оварјуће аріуумение

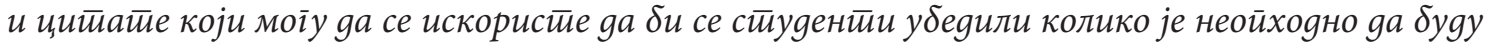
сирремни за доживойно учене.

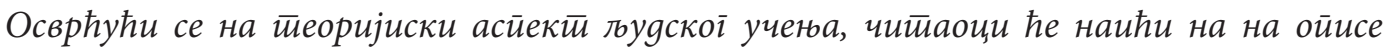
фаза и различитиих извора који су неойходни за самореіуулисано учеюе. Настиявници физике

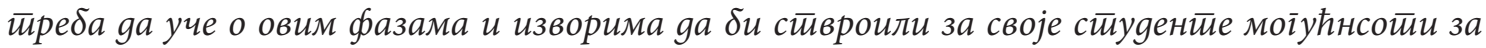

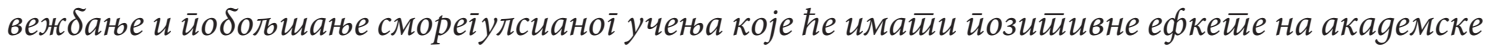
резулйайе.

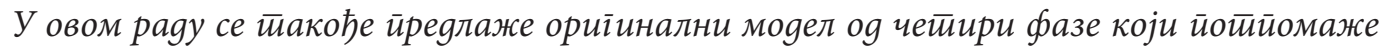

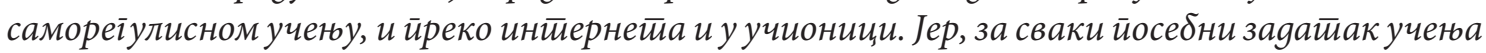
који може gа буgе „решаваюе ирроблема из физике“ или „ирроналажене објашюења за физички феномен", ирва фаза је решаване ироблема кол куће и слане своі решень или објашненьа са ойкривеним ирроблемима или неgоумицама имејлом. Друїа фаза је іруйна gискусија тичних

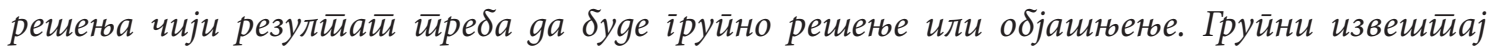

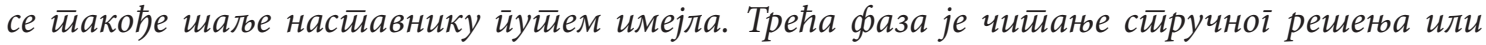

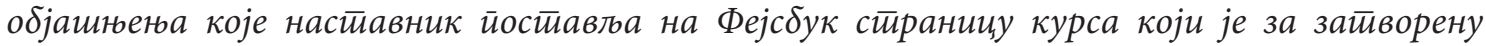

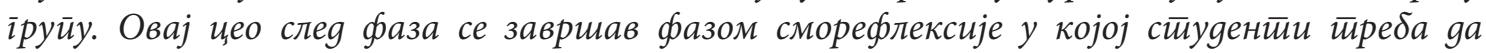

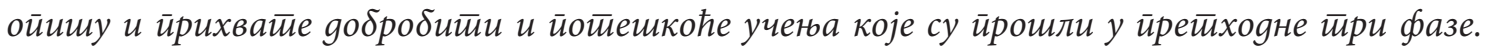

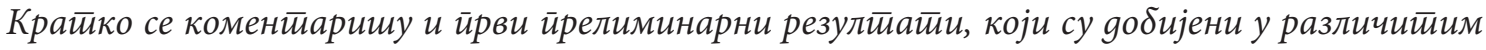
имйлеменйацијама самореїулисаної ӣроцеис учења .

Клучне речи: акитивно учене физике, самореі̄улисани ӣроцес учена, економија заснована на знану. 